This is a post-print version of the following article: Physicochemical properties and starch digestibility of Scirpus grossusflour and starch.

DOI: 10.1016/j.carbpol.2013.05.001

\title{
Physicochemical properties and starch digestibility of Scirpus grossus flour and starch
}

\author{
Chutima Lerdluksamee ${ }^{\mathrm{a}}$, Khongsak Srikaeo ${ }^{\underline{a}}$, Josep Anton Mir Tutusaus ${ }^{\underline{b}}$, Juan García Diéguez ${ }^{\mathfrak{c}}$ \\ ${ }^{a}$ Faculty of Food and Agricultural Technology, Pibulsongkram Rajabhat University, Muang, \\ Phitsanulok 65000, Thailand \\ b Autonomous University of Barcelona, Passeig de Setembre, Cerdanyola del Vallès 08290, \\ Spain \\ ${ }^{c}$ University of Pablo de Olavide, Ctra. de Utrera, Sevilla 41013, Spain
}

\section{Abstract}

Flour and starch isolated from the tubers of Scirpus grossus were investigated for their physicochemical properties and starch digestibility. The flour was extracted using two different processes namely peeled and unpeeled processes. Proximate analysis revealed that the flours from both processes contain considerably high total starch, more than $80 \%$, which indicate their potential use as starchy foods. The amylose content of the flours and starches ranged from 29 to $32 \%$. Starch granules of S. grossus were oval in shape with smooth surface and small diameters ranging from 6 to $15 \mu \mathrm{m}$. All samples exhibited high swelling pasting behaviors with pasting temperatures ranging from 78 to $79{ }^{\circ} \mathrm{C}$, indicating the strong bonding forces within the granule interiors. Differential scanning calorimetry (DSC) results suggested that the samples gelatinized at temperatures ranging from 71 to $81{ }^{\circ} \mathrm{C}$. In vitro starch digestion assay found that all samples provided the estimated glycaemic index (GI) values of approximately 55 or less.

\section{Highlights}

-The flour and starch of Scirpus grossus have the potential to be used as starchy foods.

-Their functional properties have not yet been investigated.

-This study determined their physicochemical properties.

-The findings here suggested that it could be used in low GI food products.

Ke ywords

- Scirpus grossus;

- Starch;

- Flour;

- Physicochemcal property;

- Starch digestibility 


\section{Introduction}

Wetlands are vital ecosystems which perform some important functions in relation to climate changes such as their ability to sink carbon, store and regulate water. The plants of wetland ecosystems played fascinating role in the life of human beings in earlier days as food, fodder, medicine, etc. But with the advancement of life pattern, the uses of wetland plants are foregone and they are treated as noxious weeds ( $\underline{\text { Swapna, }}$ Prakashkumar, Anoop, Manju, \& Rajith, 2011). Currently, with rising concerns on climate changes and food security, wetland plants have gained interest with particularly as food sources. The potentials of these plants for use as foods rely on their tuber and root starches. Recent researches have investigated structure and physicochemical properties of several underutilized tropical tuber and root starches ( $\underline{\text { Hoover, }}$ $\underline{2001}$ and Jayakody et al., 2005, Jayakody, Hoover, Liu, \& Donner, 2007).

Scirpus grossus, is a wetland weed of the family Cyperaceae which are perennial grasslike plants and can grow to $3 \mathrm{~m}$ tall in shallow water or in moist soils. The most important reserve substance in the rhizome of Cyperaceae is starch, which accounts for $15 \%$ of fresh weight in winter. During the formation of new shoots in spring almost all the starch is mobilized (Steinmann \& Brändle, 1984). Local people who make use of these rhizomes harvest them during winter. Like other tuber and root starches, many of the developing world's poorest and most food insecure households look to these crops as a contributing, if not the principle, source of food, nutrition and cash income. Among other things, farm households see the value of roots and tubers in their ability to produce edible energy and in their capability to generate yields under conditions where other crops may fail.

Among many species of the family Cyperaceae, Cyperus rotundus has received much attention. The plant is one of the most invasive weeds known, having spread out to a worldwide distribution in tropical and temperate regions. C. rotundus has been called "the world's worst weed" as it is known as a weed in over 90 countries and infests over 50 crops worldwide. On the other hand, it is a traditional herbal medicine used widely as analgesic, sedative, antispasmodic, antimalarial, stomach disorders and to relieve diarrhea ( Zhu, Luk, Fung, \& Luk, 1997). The tuber part of C. rotundus is one of the oldest known medicinal plants used for the treatment of dysmenorrhea and menstrual irregularities ( Bhattarai, 1993). Infusion of this herb has been used in pain, fever, diarrhea, dysentery, an emmenagogue and other intestinal problems (Uddin, Mondal, Shilpi, \& Rahnan, 2006). Umerie and Ezeuzo (2000) have reported that the C. rotundus starch is used in the food and confectionary industries. Phytochemical studies have shown that the major chemical components of this herb are essential oils, flavonoids, terpenoids, mono- and sesquiterpenes ( Ohira et al., 1998 and Kilani et al., 2005). Several investigators have reported its potential in antibacterial, antioxidant, cytotoxic and apoptotic activities ( Ardestani and Yazdanparast, 2007 and Kilani et al., 2008).

In the Cyperaceae family, $S$. grossus which is found extensively in South East Asia has not yet been investigated for its potential application. Though, local people extract its tuberous flour and use as foods. The yields are considerably high due to the large size of the tubers when compared to other species in the family ( Fig. 1). This study investigated the physicochemical properties and starch digestibility of $S$. grossus flour and starch isolated from the tubers in order to find the potential as functional food source. 

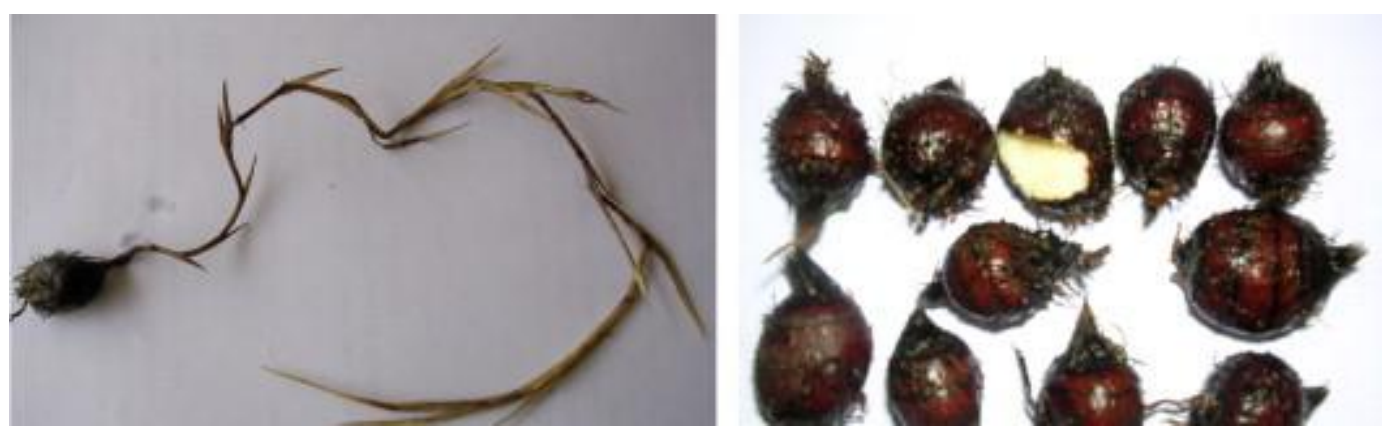

Fig. 1.

Appearances of $S$. grossus (dried stems and leaves) and their tubers.

\section{Materials and methods}

\subsection{Mate rials}

S. grossus tubers were purchased from local markets in Phitsanulok Province, Thailand during winter of 2011.

\subsection{Flour preparation}

The tubers were brushed in tap water to remove adhering dirt. Flour was prepared by two different methods (peeled and unpeeled). These two processes represent the methods used by local people and industry. The peeled and unpeeled tubers (wet forms) were ground using a mortar. Distilled water was added at the ratio of 1:3 (sample:water) and the samples were ground using a blender until fine particles were obtained. The ground samples were sieved through a 100-mesh screen and rewashed with water for three times. The extracted flour was dried at $50{ }^{\circ} \mathrm{C}$ until the moisture content reached $10-13 \%$. Notably that drying at $50{ }^{\circ} \mathrm{C}$ in this study cannot anneal starches in the samples as the water content is not sufficient, only excess water (more than $60 \%, \mathrm{w} / \mathrm{w}$ ) can induce annealing process (Tester \& Debon, 2000). The samples were sieved through a 100-mesh screen.

\subsection{Starch extraction}

Starch was isolated from the flour (unpeeled samples) using the alkaline extraction method (Lee, Htoon, \& Paterson, 2007). The flour was dispersed in water (1:10, w/w) and $\mathrm{pH}$ was adjusted to 9 by adding $0.1 \mathrm{M} \mathrm{NaOH}$, and then stored at $30{ }^{\circ} \mathrm{C}$ for $2 \mathrm{~h}$. The slurry was filtered through a 100-mesh sieve. The filtrate was centrifuged at $3000 \times g$ for $30 \mathrm{~min}$. After centrifugation, the supernatant was discarded and the yellow layer (fat) was manually scraped off. The sediment or starch portion was washed with $0.01 \%$ sodium metabisulfite. Subsequently, it was washed three times with water and centrifuged at $3000 \times g$ for $15 \mathrm{~min}$. The starch portion was filtered again through a 100 mesh sieve and dried in a hot-air oven at $50{ }^{\circ} \mathrm{C}$ for $16 \mathrm{~h}$. The dried starch samples were ground using a hammer mill fitted with a $0.5-\mathrm{mm}$ sieve and sifted through 100 mesh sieve. 


\subsection{Physicochemical properties}

\subsubsection{Proximate analysis, total starch and amylose content}

Proximate analysis was determined using standard AOAC methods (AOAC, 2000). Total starch was determined enzymatically using the total starch assay kit (Megazyme International, Ireland) following the standard AOAC Method 996.11. About $100 \mathrm{mg}$ of sample was wetted with ethanol, mixed in $\mathrm{KOH}$ and sodium ace tate buffer ( $\mathrm{pH} 3.8$ ). The samples were digested with thermo-stable $\alpha$-amylase and amyloglucosidase and incubated at $50{ }^{\circ} \mathrm{C}$ for $30 \mathrm{~min}$. The glucose released was determined using an enzymatic glucose reagent (GOPOD method), and the absorbance of the coloration was measured spectrophotometrically at $510 \mathrm{~nm}$. For amylose, it was determined by colorimetric measurement of the blue amylose-iodine complex (Juliano, 1971). The samples were analyzed in triplicate.

\subsubsection{Scanning electron microscope (SEM)}

Dried samples were dispersed on double-stick adhesive tapes mounted on SEM aluminum stubs, coated with a thin layer of gold in a vacuum evaporator (EMITEX K 550X), and examined with the SEM (Phillips XL30) at 1000-1500 magnifications.

\subsubsection{Swelling power and solubility}

The solubility and swelling power were obtained using the method from Schoch (1964) with slight modifications. Samples $(0.5 \mathrm{~g})$ were dispersed in $15 \mathrm{~mL}$ distilled water. The suspensions were heated to $55,65,75,85^{\circ} \mathrm{C}$ in a water-bath with periodic mixing over a $30 \mathrm{~min}$ period. The cooked paste samples were centrifuged at $2200 \mathrm{rpm}$ for $15 \mathrm{~min}$. The supernatants were taken and placed in pre-weighed aluminum can before drying at $105{ }^{\circ} \mathrm{C}$ to gain constant weight. The dried supernatants were weighed as soon as the samples reached room temperature. After the supernatants were removed the swollen sediment samples were weighed. The solubility and swelling power were then calculated using Eqs. (1) and (2):

equation(1)

Solubility $(\%)=\frac{\text { Weight of soluble matter in supernatant }(\mathrm{g})}{\text { Weight of sample }(\mathrm{g} \text { dry basis })} \times 100$

equation(2)

Swelling power (\%)

$$
=\frac{\text { Weight of swollen matter }(\mathrm{g})}{\text { Weight of sample }(\mathrm{g} \text { dry basis }) \times(100-\text { solubility })} \times 100
$$




\subsubsection{Pasting properties by Rapid Visco-Analyser (RVA)}

Pasting properties were investigated using the Rapid Visco-Analyser (RVA-4D, Newport Scientific Pvt. Ltd., Australia) following the approved method 61.02 ( $\underline{\text { AACC, }}$ 2009). A 13-min RVA profile was used with 3.0 g ground samples (adjusted to $14 \%$ moisture content) in $25 \mathrm{~mL}$ distilled water. The RVA Thermocline ${ }^{\mathrm{TM}}$ software (ver. 2.6) was used to obtain the RVA profiles and pasting characteristics. Each sample was analyzed in triplicate.

\subsubsection{Differential scanning calorimetry (DSC)}

Distilled water was added into the dried samples at the ratio of $3: 1(\mathrm{w} / \mathrm{w})$. The DSC (Mettler Toledo DSC 1) equipped with a refrigerated cooler was used. The hydrated samples $(20 \pm 5 \mathrm{mg})$ were weighed into the aluminum DSC pans and hermetically sealed. An empty pan was used as the reference, and DSC analysis was done by scanning from 30 to $120{ }^{\circ} \mathrm{C}$, ramping at $10{ }^{\circ} \mathrm{C} / \mathrm{min}$. Nitrogen was used as a purged gas. The resulting thermograms were analyzed using Mettler Toledo Star ${ }^{\mathrm{e}}$ software (ver. 9.20) for the onset temperature $\left(T_{\mathrm{o}}\right)$, peak temperature $\left(T_{\mathrm{p}}\right)$, conclusion temperature $\left(T_{\mathrm{c}}\right)$ and transition enthalpy $(\Delta \mathrm{H})$. Each sample was analyzed in triplicate.

\subsection{In vitro starch diges tibility and mode ling of s tarch digestogram}

Time-course starch digestion in the samples was determined using a rapid in vitro digestibility assay based on glucometry (Mahasukhonthachat et al., 2010 and Sopade and Gidley, 2009). About $0.5 \mathrm{~g}$ of ground sample was treated with artificial saliva containing porcine $\alpha$-amylase (Sigma A-3176 Type VI-B) before pepsin (Sigma P6887; $\mathrm{pH} 2.0$ ) was added and incubated at $37{ }^{\circ} \mathrm{C}$ for $30 \mathrm{~min}$ in a reciprocating water bath $(85 \mathrm{rpm})$. The digesta was neutralized with $\mathrm{NaOH}$ before adjusting the $\mathrm{pH}$ to 6 (sodium acetate buffer) prior to the addition of pancreatin (Sigma P1750) and AMG (Sigma A-7420). The mixture was incubated for $4 \mathrm{~h}$, during which the glucose concentration in the digesta was measured with an Accu-Check ${ }^{\circledR}$ Performa ${ }^{\circledR}$ glucometer at specific periods $(0,10,20,30,45,60,90,120,150,180,210$ and $240 \mathrm{~min})$. Digested starch per 100 g dry starch $(D S)$ was calculated as in Eq. (3):

equation(3)

$$
D S=\frac{0.9 \times G_{G} \times 180 \times V}{W \times S[100-M]}
$$

where $G_{G}=$ glucometer reading $(\mathrm{mM} / \mathrm{L}), V=$ volume of digesta $(\mathrm{mL}), 180=$ molecular weight of glucose, $W=$ weight of sample $(\mathrm{g}), S=$ starch content of sample (g/100 g sample), $M=$ moisture content of a sample ( $\mathrm{g} / 100 \mathrm{~g}$ sample), and $0.9=$ stoichiometric constant for starch from glucose contents.

The digestogram (digested starch at a specific time period) of each sample was modeled using a modified first-order kinetic model, Eq. (4), as described before (Mahasukhonthachat et al., 2010): 
equation(4)

$\mathrm{D}_{\mathrm{t}}=\mathrm{D}_{0}+\mathrm{D}_{\infty-0}(1-\exp [-\mathrm{Kt}])$

where $D_{t}(\mathrm{~g} / 100 \mathrm{~g}$ dry starch $)$ is the digested starch at time $t, D_{0}$ is the digested starch at time $t=0, D_{\infty}$ is the digestion at infinite time $\left(D_{0}+D_{\infty-0}\right)$, and $K$ is the rate constant $\left(\mathrm{min}^{-1}\right)$.

The Microsoft Excel Solver ${ }^{\circledR}$ was used to compute the parameters of the model by minimizing the sum of squares of residuals (SUMSQ) and constraining $D_{\infty} \leq 100 \mathrm{~g}$ per $100 \mathrm{~g}$ dry starch, and $D_{0} \geq 0 \mathrm{~g}$ per $100 \mathrm{~g}$ dry starch. In addition to the coefficient of determination $\left(r^{2}\right)$, the predictive ability of the models was assessed with the mean relative deviation modulus (MRDM) as described elsewhere (Mahasukhonthachat et al., $\underline{2010)}$.

In order to calculate the estimated glycaemic indices (GIs) of the samples, the areas under the digestograms $\left(A U C_{\text {exp }}\right)$ were computed with Eq. (5):

equation(5)

$\mathrm{AUC}_{\exp }=\left[D_{\infty} t+\frac{D_{\infty}-0}{K} \exp (-K t)\right]_{t_{1}}^{t_{2}}$

The hydrolysis index $(\mathrm{HI})$ of each sample was calculated by dividing the area under its digestogram by the area under the digestogram of a fresh white bread, which was calculated to be about 13,000 min g/100 g dry starch from 0 to $240 \mathrm{~min}$ (Yong, Chan, Garcia, \& Sopade, 2010). Single-point measurement of starch digestion at $90 \mathrm{~min}$ in the samples was also used to calculate GI $\left(\mathrm{H}_{90}\right)$. Hence, using the parameters of the modified first-order kinetic model for both the samples and fresh white bread, GIs of the samples were also calculated, and the average $\mathrm{GI}\left(\mathrm{GI}_{\mathrm{AVG}}\right)$ for each sample (Goni,

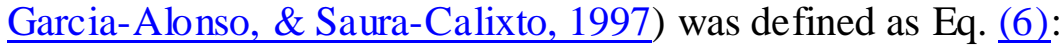

equation(6)

$\mathrm{GI}_{\mathrm{AVG}}=\left[\frac{\left(\left(39.21+0.803 H_{90}\right)+(39.51+0.573 \mathrm{HI})\right)}{2}\right]$

\subsection{Statis tical analys is}

Analysis of variance (ANOVA) and test of significance were performed using SPSS ${ }^{\circledR}$ ver. 16 with confidence level of $95 \%$. The samples were randomized for all the analyses described above. 


\section{Results and discussions}

\subsection{Physicochemical properties}

\subsubsection{Proximate analysis, total starch and amylose content}

Proximate analysis, total starch and amylose content are shown in Table 1. S. grossus flours (both peeled and unpeeled samples) contain considerably high total starch content, more than $80 \%$, which indicate their potential as carbohydrate foods. Notably that total starch from peeled-process flour is as high as total starch from isolated starch sample. Hoover (2001) reviewed the published literatures and found that starch yield of many tuber and root starches ranged from 30 to $88 \%$. It is highlighted here again that $S$. grossus contain high starch yield as compared to other tuber and root starchy plants.

Amylose content of starch from S. grossus ranged from 29 to $32 \%$ and processing methods affected the amylose content. Peeled process provided the flour with high amylose content as this process had less contaminants.

Table 1. Total starch, amylose and proximate analysis of the samples ( $\mathrm{g} / 100 \mathrm{~g}$ dry sample).

\begin{tabular}{lcccccc}
\hline \multicolumn{1}{c}{ Samples } & Total starch & Amylose & Protein & Fat & Crude fiber & Ash \\
\hline $\begin{array}{l}\text { Starch } \\
\text { Flour- } \\
\text { peeled }\end{array}$ & $87.69 \pm 0.77^{\mathrm{a}}$ & $32.33 \pm 0.58^{\mathrm{a}}$ & $0.17 \pm 0.02^{\mathrm{c}}$ & $0.06 \pm 0.01^{\mathrm{b}}$ & $0.08 \pm 0.01^{\mathrm{c}}$ & $0.09 \pm 0.00^{\mathrm{c}}$ \\
$\begin{array}{l}\text { Flour- } \\
\text { unpeeled }\end{array}$ & $80.43 \pm 1.28^{\mathrm{a}}$ & $30.44 \pm 0.51^{\mathrm{b}}$ & $0.32 \pm 0.01^{\mathrm{b}}$ & $0.12 \pm 0.01^{\mathrm{a}}$ & $1.43 \pm 0.18^{\mathrm{b}}$ & $0.34 \pm 0.09^{\mathrm{b}}$ \\
\hline
\end{tabular}

Values are means \pm standard deviations. For each parameter (column), values with the same letters are not significantly different $(P>0.05)$.

Amylose content of starch from S. grossus ranged from 29 to $32 \%$ and processing methods affected the amylose content. Peeled process provided the flour with high amylose content as this process had less contaminants.

\subsubsection{SEM}

SEM images of the flour samples showing starch granules attached with other components e.g. protein (smaller sizes) are shown in Fig. 2. The granules were found to be oval in shape with smooth surface similar to potato starches. The diameter of starch granules ranged from 6 to $15 \mu \mathrm{m}$ which is considered to be small when compared to other starch types e.g. potato $(10-65 \mu \mathrm{m})$ (Yuan, Zhang, Dal, \& Yu, 2007).

Morphological characteristics of starches from different plant sources vary with the genotype. The variation in the size and shape of starch granules is attributed to the biological origin (Svegmark \& Hermansson, 1993). Physicochemical properties, such as percent light transmittance, amylose content, swelling power and water-bind ing capacity were significantly correlated with the average granule size of the starches separated from different plant sources (Singh et al., 2003 and Zhou et al., 1998). The smaller granule sizes have been found to improve the digestibility because smaller granules have a greater surface area and are more rapidly digested by enzymes ( $\underline{\text { Cone }}$ and Wolters, 1990, Franco et al., 1992 and Riley, 2004). 

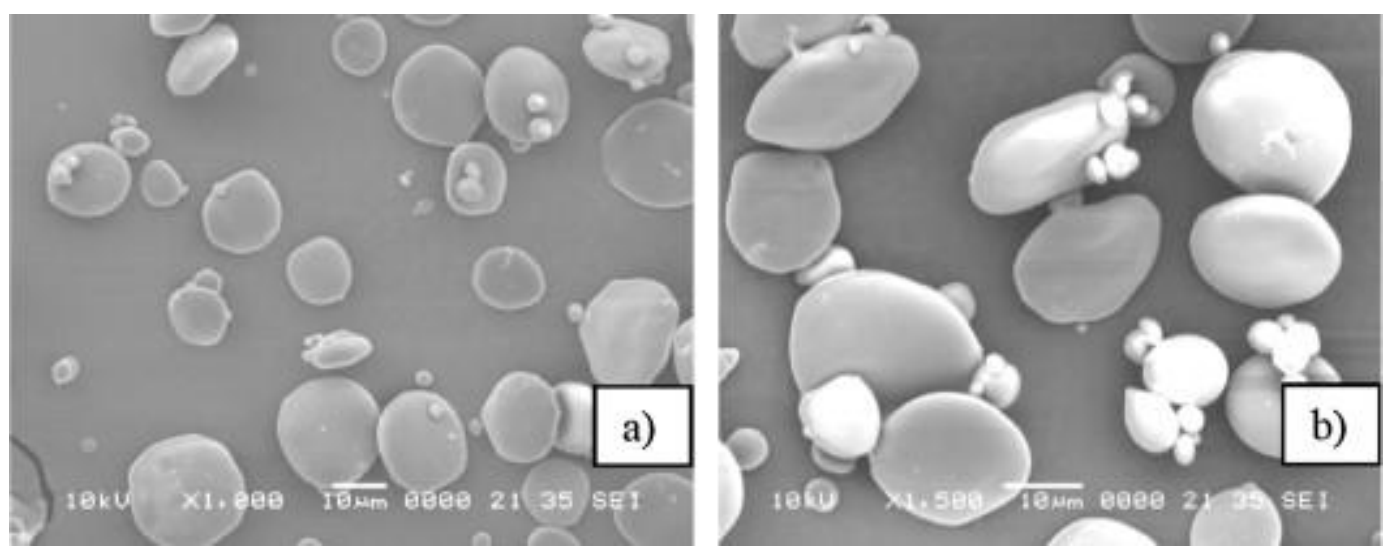

Fig. 2. SEM images of S. grossus flours, (a) unpeeled and (b) peeled sample.

Apart from morphological properties, molecular structure of starches as obtained by size exclusion chromatography and/or fluorophore-assisted capillary electrophoresis is suggested.

\subsubsection{Swelling power and solubility}

Swelling power and solubility of the samples are shown in Fig. 3. The solubility is contributed by the content of amylose, and the swelling power is contributed by the content of amylopectin (Tester \& Morrison, 1990). The swelling power of all samples increased as the incubation temperature increased from 55 to $85^{\circ} \mathrm{C}$. As been known, starch could not be dissolved in cool water attributed to the starch crystal structure. However, when starch was heated in excess water, the crystalline structure was disrupted and water molecules became linked by hydrogen bonding to exposed hydrogen group of amylose and amylopectin. Then the amylose and amylopectin were dissociated in suspension, and the solubility of starch was increased (Yuan et al., 2007). From Fig. 3, S. grossus (both in the forms of flour and starch) swelled quickly from 65 to $75{ }^{\circ} \mathrm{C}$, and they had dissolved well when temperature increased from 65 to $75{ }^{\circ} \mathrm{C}$. From this study, the swelling power and solubility patterns of $S$. grossus flour and starch samples were found to be similar to those of other tuber starches. Yuan et al. (2007) reported that, as temperatures increased from 55 to $85{ }^{\circ} \mathrm{C}$, swelling power of potato starch increased from 8 to $68 \%$ while solubility increased from 3 to $35 \%$. Thus, the results from this paper indicated that the granule structure of $S$. grossus starch has single-step swelling process which is similar to potato and tapioca starches and this is different from cereal starches. Generally, cereal starches have two-step swelling process. The first stage of swelling $\left(45-55^{\circ} \mathrm{C}\right)$ occurs when heating starch from 55 to $60{ }^{\circ} \mathrm{C}$ and dissociation of amylopectin double-helices is exhibited. This makes amylopectin swells in highly extent, while the starch granules still exist through intermolecular (might be hydrogen) bonding. From this evidence, amylopectin would promote starch swelling, especially at the early stage of swelling. Amylose would leach out during heating process particularly at the higher temperature (the later stage of swelling).

Comparing among all studied samples, the flour (unpeeled process) exhibited the lowest swelling power and solubility. This could be influenced by a strong interaction between the yarn fibers and starches (Umerie \& Ezeuzo, 2000). 

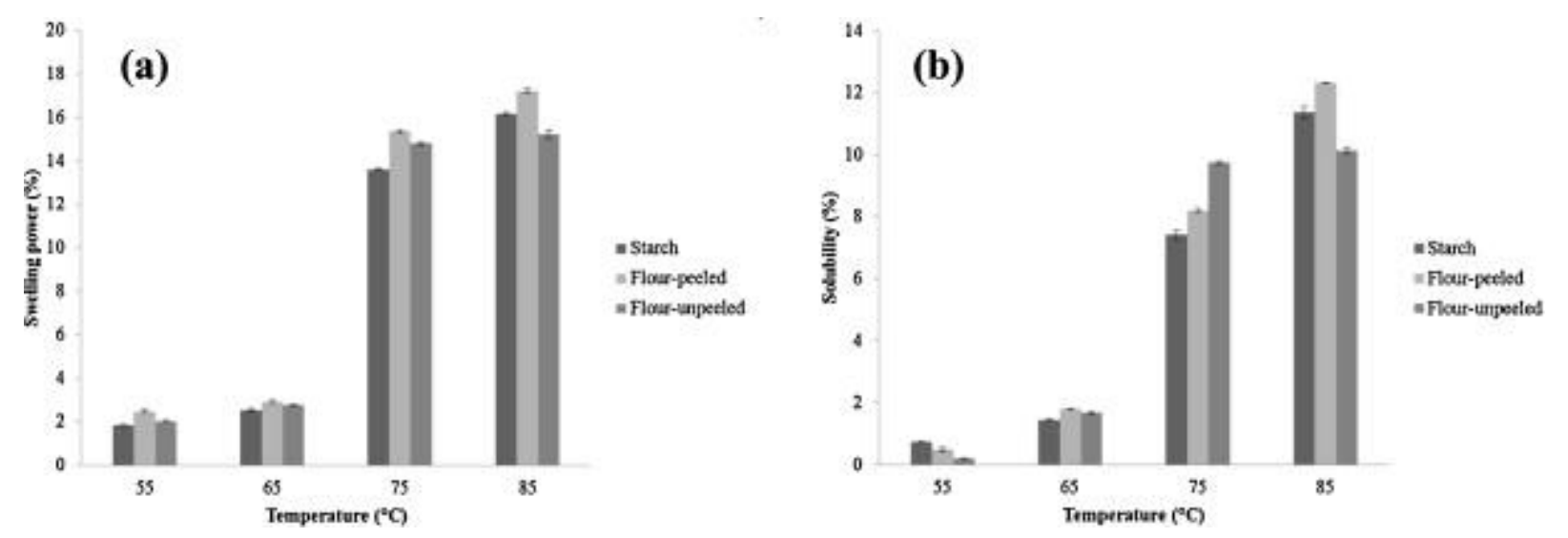

Fig. 3. Swelling power and solubility of $S$. grossus starch.

\subsubsection{Pasting properties by RVA}

Table 2 shows the pasting properties of $S$. grossus flour and starch samples. All the samples exhibited high pasting temperatures and thermal stability as indicated by breakdown values. Notably that the pasting temperatures of all samples ranged from 78 to $79{ }^{\circ} \mathrm{C}$ which were high when compared to other tuber and root starches as summarized by Hoover (2001). This suggests the strong bonding forces within the granule interiors. In addition, with its high in peak viscosity and final viscosity, it can be said to have high water biding capacity. Similar pasting pattern was found in another root starch, edible canna ( Piyachomkwan et al., 2002, Srikaeo et al., 2011, Thitipraphunkul et al., 2003, Watcharatewinkul et al., 2009 and Yanika et al., 2009). Generally, starches with high viscosity are desirable for industrial uses, for which a high thickening power at high temperature can be obtained (Kim, Wiesnborg, Orr, \& Gant, 1995). However, it should be noted that $S$. grossus starch showed considerably high setback values. This indicated that it provided a cohesive paste. It is less stable during cooling and retrograded more (Karim, Norziah, \& Seow, 2000). Thus, the pasting properties showed that starch from $S$. grossus was not suitable for products in which stability is required at low temperatures e.g. fillings and refrigerated products.

\subsubsection{DSC}

DSC results suggested that $S$. grossus flour and starch samples gelatinized at the temperatures ranging from 71 to $81{ }^{\circ} \mathrm{C}$ (Table 3). Onset temperatures of the samples were found to be slightly higher than those found in most tuber and root starches ( Bernabé et al., 2011, Hoover, 2001, Jane et al., 1992, Pérez and Lares, 2005 and Srikaeo et al., 2011). This result seems to support the findings from RVA, though DSC and RVA measure different properties of starch in excess water. It could be summarized in this study that $S$. grossus flour and starch are high in thermal stability and gelatinized at high temperatures when compared to other tuber and root starches. Gelatinization temperatures of the starchy samples can vary due to factors that include genetic origin, environmental conditions and age of the parent plant (da Mota et al., 2000, $\underline{\text { Hung and }}$ Morita, 2005, Jane et al., 1999 and Moorthy, 2002). High-amylose starches with longer average chain have been reported to exhibit higher transition temperatures (Jane et al., 1992). 
Table 2. RVA parameters of the samples.

$\begin{array}{lcccccc}\text { Samples } & \begin{array}{c}\text { Peak } \\ \text { temperature } \\ \left({ }^{\circ} \mathbf{C}\right)\end{array} & \begin{array}{c}\text { Peak } \\ \text { viscosity } \\ (\mathbf{R V U})\end{array} & \begin{array}{c}\text { Trough } \\ \text { viscosity } \\ (\mathbf{R V U})\end{array} & \begin{array}{c}\text { Breakdown } \\ \text { viscosity } \\ (\mathbf{R V U})\end{array} & \begin{array}{c}\text { Final } \\ \text { viscosity } \\ (\mathbf{R V U})\end{array} & \begin{array}{c}\text { Setback } \\ \text { viscosity } \\ (\mathbf{R V U})\end{array} \\ \begin{array}{l}\text { Starch } \\ \text { Flour- } \\ \text { peeled }\end{array} & 78.33 \pm 0.22^{\mathrm{b}} & 285.8 \pm 0.25^{\mathrm{b}} & 207.4 \pm 0.35^{\mathrm{a}} & 78.70 \pm 0.99^{\mathrm{c}} & 280.4 \pm 0.21^{\mathrm{a}} & 73.02 \pm 0.56^{\mathrm{b}} \\ \begin{array}{l}\text { Flour- } \\ \text { unpeeled }\end{array} & 79.14 \pm 0.05^{\mathrm{a}} & 262.7 \pm 0.31^{\mathrm{c}} & 180.5 \pm 0.48^{\mathrm{b}} & 82.53 \pm 0.71^{\mathrm{b}} & 254.5 \pm 0.02^{\mathrm{b}} & 74.02 \pm 0.52^{\mathrm{b}} \\ & & 293.6 \pm 0.52^{\mathrm{a}} & 173.5 \pm 0.47^{\mathrm{c}} & 120.1 \pm 0.17^{\mathrm{a}} & 249.6 \pm 0.38^{\mathrm{c}} & 76.06 \pm 0.57^{\mathrm{a}} \\ & & & & & & \end{array}$

Values are means \pm standard deviations. For each parameter (column), values with the same letters are not significantly different $(P>0.05)$.

Table 3. DSC parameters of the samples.

\begin{tabular}{lcccl}
\multicolumn{1}{c}{ Samples } & $\boldsymbol{T}_{\mathbf{0}}\left({ }^{\circ} \mathbf{C}\right)$ & $\boldsymbol{T}_{\mathbf{p}}\left({ }^{\circ} \mathbf{C}\right)$ & $\boldsymbol{T}_{\mathbf{c}}\left({ }^{\circ} \mathbf{C}\right)$ & $\Delta \boldsymbol{H}(\mathbf{J} / \mathbf{g}$ dry sample $)$ \\
Starch & $73.34 \pm 1.03^{\mathrm{a}}$ & $75.48 \pm 0.21^{\mathrm{a}}$ & $81.14 \pm 0.14^{\mathrm{a}}$ & $16.48 \pm 0.28^{\mathrm{a}}$ \\
Flour-peeled & $70.74 \pm 0.25^{\mathrm{b}}$ & $73.23 \pm 0.25^{\mathrm{c}}$ & $77.51 \pm 0.10^{\mathrm{c}}$ & $12.74 \pm 0.14^{\mathrm{b}}$ \\
Flour-unpeeled & $70.95 \pm 0.07^{\mathrm{b}}$ & $73.79 \pm 0.08^{\mathrm{b}}$ & $78.85 \pm 0.13^{\mathrm{b}}$ & $16.58 \pm 0.76^{\mathrm{a}}$
\end{tabular}

Values are means \pm standard deviations. For each parameter (column), values with the same letters are not significantly different $(P>0.05)$.

\subsection{In vitro starch digestibility and mode ling of s tarch digestogram}

Fig. 4 shows the starch digestogram while Table 4 shows the digestion data of the samples. It was found that the modified first-order kinetic model, was suitable $\left(r^{2}=0.95-0.99 ; \mathrm{MRDM}=1-14 \%\right.$; SUMSQ $\left.=5-87\right)$ in describing the digestograms. Generally, all samples provided the average GI values for about 55 or less which indicate that most of them are low in GI. It is widely recognized that low GI foods are valuable for use in controlled glucose release applications and in lowering insulin response, and greater access to the use of stored fat is expected ( Nugent, $\underline{2005}$ and Sajilata et al., 2006). This is important for diabetes and its dietary management. The present study showed that native $S$. grossus flour and starch can have the potential of being used as functional food ingredients for low GI foods. This appears to support the conclusions of Moorthy (2002) and Srikaeo et al. (2011) that some tropical tuber and root crop starches have the potential to be used in low GI foods. Comparing among all samples, $S$. grossus starch has higher digestion rate than tho se of the flours. However, the starch sample contains more amylose than the flour samples. Amylose content was reported to have an obvious impact on GI values. Slow digestion rate and consequently low GI values were expected with increased amylose content as studied in rice ( $\mathrm{Hu}$, Zhao, Duan, Linlin, \& Wu, 2004). In this study, the starch sample which contained higher amylose gave higher digestion rate than those observed from 
the flour samples. Starch digestion rate and the GI of foods depends upon various factors such as starch granule morphology, amylose to amylopectin ratio, molecular structure, degree of branching in terms of steric hindrance, and consequently mass transfer resistance ( Fuentes-Zaragoza et al., 2010 and Singh et al., 2010). The other components in the flour samples of $S$. grossus could also have the impact on digestion rate.

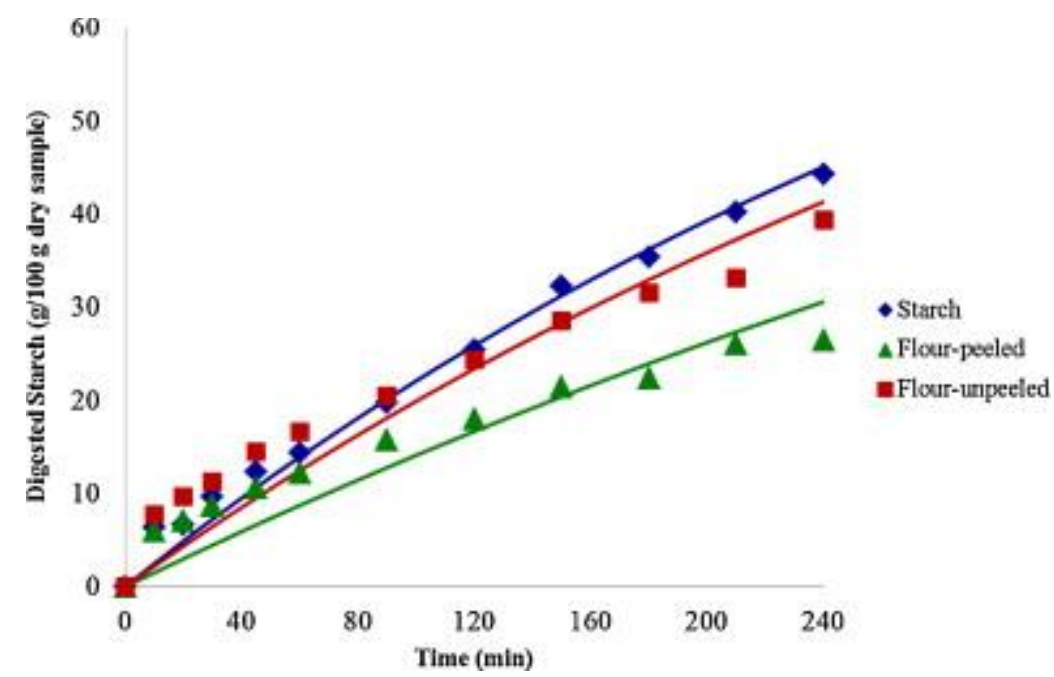

Fig. 4.

Digestograms of $S$. grossus starch and flours.

It should be noted that the digestion data in this study were based on the raw starch and flour samples. They can be different for cooked flour and starch. Generally, in the absence of retrogradation or structural changes, starch gelatinization enhances starch digestibility. Therefore, cooked samples could exhibit higher GI values than raw samples. Moreover, the results were also based on in vitro starch digestion assay. It is valid for comparison and useful for preliminary study of starch digestibility. Real digestion data and GI can be obtained by the in vivo assay. Further study is recommended.

Table 4. Model parameters, hydrolysis index (HI) and glycaemic index (GI) of the samples.

\begin{tabular}{lllccc}
\multicolumn{1}{c}{ Samples } & $\boldsymbol{D}_{\mathbf{0}}(\mathbf{g} / \mathbf{1 0 0} \mathbf{g}$ dry starch $)$ & $\boldsymbol{K} \times \mathbf{1 0}^{-\mathbf{3}}\left(\mathbf{m i n}^{-\mathbf{1}}\right)$ & $\mathbf{G I}_{\mathbf{H 9 0}}$ & $\mathbf{G I}_{\mathbf{H I}}$ & A verage GI \\
Starch & $4.13 \pm 0.91^{\mathrm{b}}$ & $2.20 \pm 0.53^{\mathrm{a}}$ & $56.4 \pm 0.29^{\mathrm{a}}$ & $54.4 \pm 0.15^{\mathrm{a}}$ & $55.4 \pm 0.23^{\mathrm{a}}$ \\
Flour-peeled & $5.44 \pm 0.21^{\mathrm{ab}}$ & $1.13 \pm 0.01^{\mathrm{c}}$ & $51.0 \pm 0.12^{\mathrm{c}}$ & $49.6 \pm 0.08^{\mathrm{c}}$ & $50.3 \pm 0.10^{\mathrm{c}}$ \\
Flour-unpeeded & $6.68 \pm 0.18^{\mathrm{a}}$ & $1.75 \pm 0.05^{\mathrm{b}}$ & $55.5 \pm 0.18^{\mathrm{b}}$ & $53.5 \pm 0.18^{\mathrm{b}}$ & $54.5 \pm 0.18^{\mathrm{b}}$
\end{tabular}

Values are means \pm standard deviations. For each parameter (column), values with the same letters are not significantly different $(P>0.05)$. 


\section{Conclusion}

S. grossus, is a wetland weed of the family Cyperaceae which has the potential of being used as a starchy food source. Physicochemical properties of its flour and starch revealed some unique characteristics such as thermal stability and granule structure stability. These properties suggested the application of its flour and starch to appropriate products. In vitro starch digestibility also found that it might be suitable for use in low GI foods. These findings could help in promoting the use of $S$. grossus as an alternative starchy food. It could also add the values to this crop and enhance food securities, as it is abundantly grown in wetlands or areas that other crops cannot grow well. 


\section{References}

AACC. (2009). AACC international approved methods of analysis (11th ed., pp. ). St. Paul, MN, USA: AACC International.

AOAC. (2000). AOAC Official Methods of Analysis (17th ed., pp. ). VA, USA: Association of Official Analytical Chemists.

Ardestani, A., \& Yazdanparast, R. (2007). Cyperus rotundus suppresses AGE formation and protein oxidation in a model of fructose mediated protein glycoxidation. International Journal of Biological Macromolecules, 41, 572-578.

Bernabé, A. M., Srikaeo, K., \& Schlüter, M. (2011). Resistant starch content starch digestibility and the fermentation of some tropical starches in vitro. Food Diges- tion, 2, $37-42$.

Bhattarai, N. K. (1993). Folk herbal remedies for diarrhoea and dysentery in central Nepal. Fitoterapia, 64, 243-250.

Cone, J. W., \& Wolters, G. E. (1990). Some properties and degradability of isolated starch granules. Starch/Stärke, 42, 298-301.

da Mota, R. V., Lajolo, F. M., Cordenunsi, B. R., \& Ciacco, C. (2000). Composition and functional properties of banana flour from different varieties. Starch/Stärke, 52, 63 68.

Franco, M. L. C., Preto, S. J. R., \& Ciacco, C. F. (1992). Factors that affect the enzymatic degradation of natural starch granules-effect of the size of the granule.

Starch/Stärke, 44, 113-116. Fuentes-Zaragoza, E., Riquelme-Navarrete, M. J., SanchezZapata, E., \& Perez- Alvarez, J. A. (2010). Resistant starch as functional ingredient: A review. Food Research International, 43, 931-942.

Goni, I., Garcia-Alonso, A., \& Saura-Calixto, F. (1997). A starch hydrolysis procedure to estimate glycemic index. Nutrition Research, 17, 427-437.

Hoover, R. (2001). Composition, molecular structure and physicochemical proper- ties of tuber and root starches: A review. Carbohydrate Polymers, 45, 253-267.

Hu, P., Zhao, H., Duan, Z., Linlin, Z., \& Wu, D. (2004). Starch digestibility and the estimated glycemic score of different types of rice differing in amylose contents. Journal of Cereal Science, 40, 231-237.

Hung, P. V., \& Morita, N. (2005). Physicochemical properties and enzymatic digestibility of starch from edible canna (Canna edulis) grown in Vietnam. Carbohydrate Polymers, 61, 314-321.

Jane, J., Shen, I., Chen, J., Lim, S., Kasemsuwan, T., \& Nip, W. K. (1992). Physical and chemical studies of taro starches and flours. Cereal Chemistry, 69, 528-535. 
Jane, J., Chen, Y. Y., Lee, L. F., McPherson, A. E., Wong, K. S., Radosavljevic, M., et al. (1999). Effects of amylopectin branch chain length and amylose content on the gelatinization and pasting properties of starch. Cereal Chemistry, 76, 629-637.

Jayakody, L., Hoover, R., Liu, Q., \& Weber, E. (2005). Studies on tuber and root starches. I. Structure and physicochemical properties of innala (Solenostemon rotundifolius) starches grown in Sri Lanka. Food Research International, 38, 615-629.

Jayakody, L., Hoover, R., Liu, Q., \& Donner, E. (2007). Studies on tuber starches. II. Molecular structure composition and physicochemical properties of yam (Dioscorea sp.) starches grown in Sri Lanka. Carbohydrate Polymers, 69, 148-163.

Juliano, B. O. A. (1971). Simplified assay for milled-rice amylose. Cereal Science Today, 16(360), 334-340.

Karim, A. A., Norziah, M. H., \& Seow, C. C. (2000). Method for the study of starch retrogradation. Food Chemistry, 71, 9-31.

Kilani, S., Abdelwahed, A., Chraief, I., Ben Ammar, R., Hayder, N., Hammami, M., et al. (2005). Chemical composition antibacterial and antimutagenic activities of essential oil from (Tunisian) Cyperus rotundus. Journal of Essential Oil Research, 17, 695-700.

Kilani, S., Ben Sghaier, M., Limem, I., Bouhlel, I., Boubaker, J., Bhouri, W., et al. (2008). In vitro evaluation of antibacterial, antioxidant cytotoxic and apoptotic activities of the tubers infusion and extracts of Cyperus rotund us. Bioresource Technology, 99, 9004-9008.

Kim, Y. S., Wiesnborg, D. P., Orr, P. H., \& Gant, L. A. (1995). Screening potato starch for novel properties using differential scanning colorimeter. Journal of Food Science, $60,1060-1065$.

Lee, H. C., Htoon, A. K., \& Paterson, J. L. (2007). Alkaline extraction of starch from Australian lentil cultivars Matilda and Digger optimized for starch yield and starch and protein quality. Food Chemistry, 102, 551-559. Mahasukhonthachat, K., Sopade, P. A., \& Gidley, M. J. (2010). Kinetics of starch digestion in sorghum as affected by particle size. Journal of Food Engineering, 96, 18-28.

Moorthy, S. N. (2002). Physicochemical and functional properties of tropical tuber starches: A review. Starch/Stärke, 54, 559-592.

Nugent, A. P. (2005). Health properties of resistant starch. British Nutrition Foundation. Nutrition Bulletin, 30, 27-54.

Ohira, S., Hase gawa, T., Hyashi, K. I., Hoshino, T., Takaoka, D., \& Nozaki, H. (1998). Sesquiterpenoids from Cyperus rotund us. Phytochemistry, 47, 1577-1581.

Pérez, E., \& Lares, M. (2005). Chemical composition, mineral profile and functional properties of canna (Canna edulis) and arrowroot (Maranta spp.) starches. Plant Foods for Human Nutrition, 60, 113-116. Piyachomkwan, K., Chotineeranat, S.,

Kijkhunasatian, C., Tonwitowat, R., Pramma- nee, S., Oates, C. G., et al. (2002). Edible 
canna (Canna edulis) as a complementary starch source to cassava for the starch industry. Industrial Crops and Products, 16, 11-21.

Riley, C. K. (2004). In vitro digestibility of raw starches extracted from five Yam species grown in Jamaica. Starch/Stärke, 56, 69-73.

Sajilata, M. G., Singhal, R. S., \& Kulkarni, P. R. (2006). Resistant starch - A review. Comprehensive Reviews in Food Science and Food Safety, 5, 1-17.

Schoch, T. J. (1964). Method of swelling power and solubility. In R. L. Whistler, R. J. Smith, \& J. N. BeMiller (Eds.), Methods in carbohydrate chemistry starch (p. 106). London, UK: Academic Press.

Singh, N., Singh, J., Kaur, L., Sodhi, N. S., \& Gill, B. S. (2003). Morphological thermal and rheological properties of starches from different botanical sources. Food Chemistry, 81, 219-231.

Singh, J., Dartois, A., \& Kaur, L. (2010). Starch digestibility in food matrix: A review. Trends in Food Science \& Technology, 21, 168-180.

Sopade, P. A., \& Gidley, M. J. (2009). A rapid in-vitro digestibility assay based on glucometry for investigating kinetics of starch digestion. Starch/Stärke, 61, 245-255.

Srikaeo, K., Mingyai, S., \& Sopade, P. A. (2011). Physicochemical properties, resistant starch content and enzymatic digestibility of unripe banana, edible canna taro flours and their rice noodle products. International Journal of Food Science and Technology, 46, 2111-2117.

Steinmann, F., \& Brändle, R. (1984). Carbohydrate and protein metabolism in the rhizomes of the bulrush (Schoenoplectus lacus tris (L.) palla in relation to natural development of the whole plant. Aquatic Botany, 19, 53-63.

Svegmark, K., \& Hermansson, A. M. (1993). Microstructure and rheological properties of composites of potato starch granules and amylose: A comparison of observed and predicted structure. Food Structure, 12, 181-193.

Swapna, M. M., Prakashkumar, R., Anoop, K. P., Manju, C. N., \& Rajith, N. P. (2011). A review on the medicinal and edible aspects of aquatic and wetland plants of India. Journal of Medicinal Plants Research, 5, 7163-7176.

Tester, R. F., \& Debon, S. J. J. (2000). Annealing of starch - A review. International Journal of Biological Macromolecules, 27, 1-12.

Tester, R. F., \& Morrison, W. R. (1990). Swelling and gelatinization of cereal starches. Cereal Chemistry, 67, 558-563. Thitipraphunkul, K., Uttapap, D., Piyachomkwan, K., \& Takeda, Y. (2003). A compar- ative study of edible canna (Canna edulis) starch from different cultivars. Part I. Chemical composition and physicochemical properties. Carbohydrate Polymers, 53, 317-324. 
Uddin, S. J., Mondal, K., Shilpi, J. A., \& Rahnan, M. T. (2006). Antidiarrhoeal activity of Cyperus rotundus. Fitoterapia, 77, 134-136.

Umerie, S. C., \& Ezeuzo, H. O. (2000). Physicochemical characterization and utilization of Cyperus rotundus starch. Biore source Technology, 72, 193-196.

Watcharatewinkul, Y., Puttanlek, C., Rungsardthong, V., \& Uttapap, D. (2009). Pasting properties of a heat-moisture treated canna starch in relation to its structural characteristics. Carbohydrate Polymers, 75, 505-511.

Yanika, W., Chureerat, P., \& Vilai, R. (2009). Pasting properties of a heat-moisture treated canna starch in relation to its structural characteristics. Carbohydrate Polymers, $75,505-511$.

Yong, L. Z., Chan, C. H., Garcia, C., \& Sopade, P. A. (2010). Weighing up whey fortification of foods: Implications for kinetics of starch digestion and estimated glycemic index of model high-protein-low-carbohydrate food systems. Carbo- hydrate Polymers, $84,162-172$.

Yuan, Y., Zhang, L. M., Dal, Y. J., \& Yu, J. G. (2007). Physicochemical properties of starch obtained from Dioscorea nipponica Makino comparison with other tuber starches. Journal of Food Engineering, 82, 436-442.

Zhou, M., Robards, K., Glennie-Holmes, M., \& Helliwell, S. (1998). Structure and pasting properties of oat starch. Cereal Chemistry, 75, 273-281.

Zhu, M., Luk, H. H., Fung, H. S., \& Luk, C. T. (1997). Cytoprotective effects of Cyperus rotundus against ethanol induced gastric ulceration in rats. Phototherapy Research, $11,392-394$. 